US Army Corps of Engineers ${ }_{\circledast}$

Engineer Research and

Development Center

\title{
Applications of Value Modeling to USACE Civil Works and Beyond
}

R. Cody Salter, Christina H. Rinaudo, Kathleen A. Staebell, June 2020

Brent H. Hargis, Kayla A. Cotterman, and Matthew D. Smith

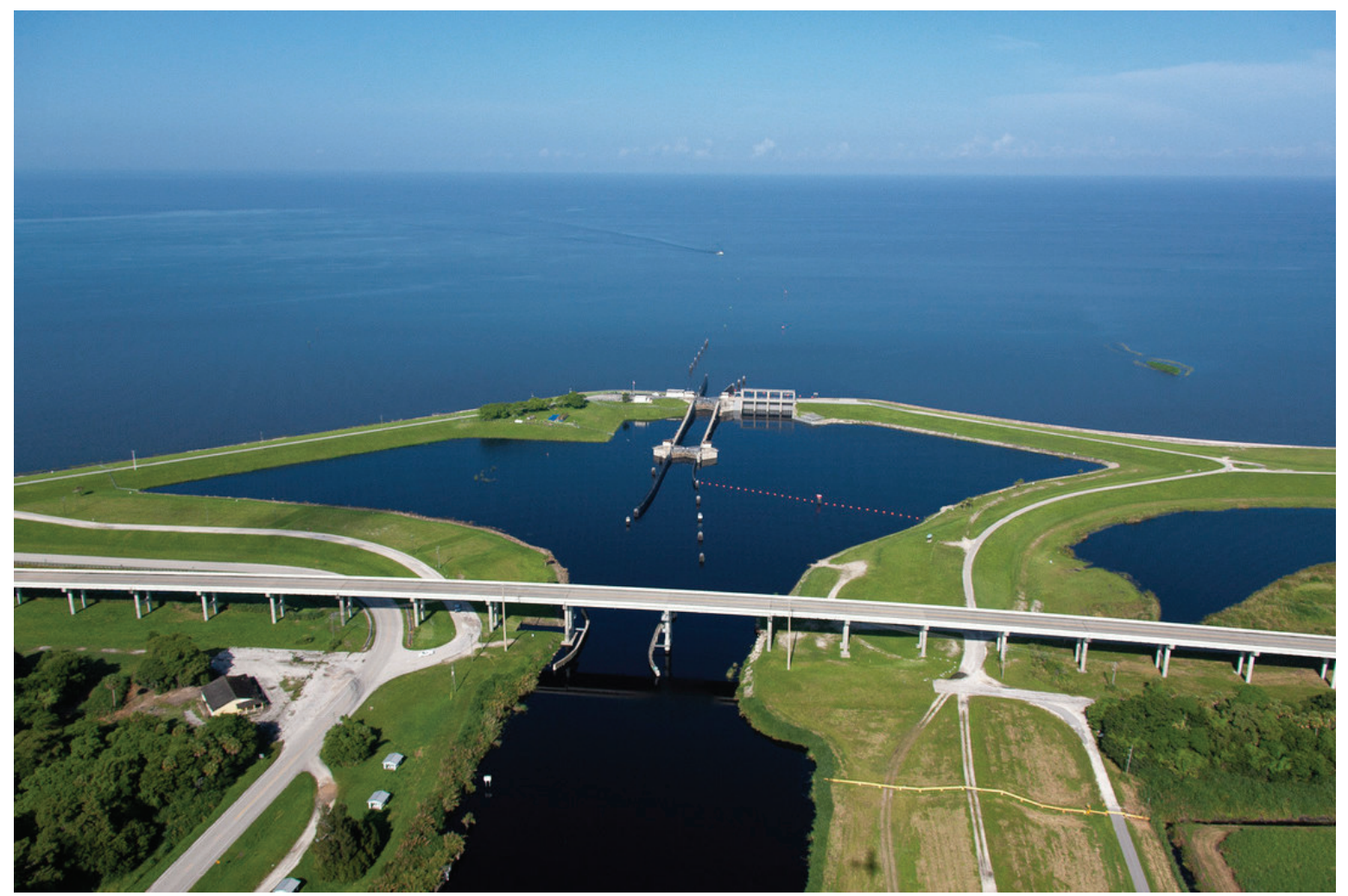


The US Army Engineer Research and Development Center (ERDC) solves the nation's toughest engineering and environmental challenges. ERDC develops innovative solutions in civil and military engineering, geospatial sciences, water resources, and environmental sciences for the Army, the Department of Defense, civilian agencies, and our nation's public good. Find out more at www.erdc.usace.army.mil.

To search for other technical reports published by ERDC, visit the ERDC online library at http://acwc.sdp.sirsi.net/client/default. 


\section{Applications of Value Modeling to USACE Civil Works and Beyond}

R. Cody Salter and Christina H. Rinaudo

Information Technology Laboratory

U.S. Army Engineer Research and Development Center

3909 Halls Ferry Road

Vicksburg, MS 39180-6199

Kathleen A. Staebell, Brent H. Hargis, Kayla A. Cotterman, and Matthew D. Smith

Coastal and Hydraulics Laboratory

U.S. Army Engineer Research and Development Center

3909 Halls Ferry Road

Vicksburg, MS 39180-6199

Final report

Approved for public release; distribution is unlimited.

Prepared for Asset Management; Headquarters, US Army Corps of Engineers

Washington, DC 20001

Monitoring Completed Navigation Projects

Vicksburg, MS 39180

Under Funding Account Code FG46LB; AMSCO Code 008321 


\section{Abstract}

The US Army Corps of Engineers (USACE) Civil Works (CW) portfolio includes $\$ 250$ billion worth of capital assets. As infrastructure ages and budgets change, new asset management (AM) investment strategies are required to support the maintenance, repair, and replacement (MR\&R) of these assets while also providing the greatest value to the USACE and to the Nation. Shrinking budgets and increased scrutiny of government expenditures drive efforts to determine how best to optimize government funds for infrastructure improvement. As a result, USACE-CW AM seeks to create a value model capable of calculating the benefit of MR\&R project alternatives regardless of business line. Furthermore, USACE-CW seeks to explore whether such a value model could be used for the generation of defensible budgets that consistently bring high value to the USACE and to the Nation. Thus, this special report reviews past USACE CW efforts to develop a value model for decision analytics. This report also provides an introduction to value modeling while covering applications of value modeling in multiple areas, including AM and portfolio decision analytics.

DISCLAIMER: The contents of this report are not to be used for advertising, publication, or promotional purposes. Citation of trade names does not constitute an official endorsement or approval of the use of such commercial products. All product names and trademarks cited are the property of their respective owners. The findings of this report are not to be construed as an official Department of the Army position unless so designated by other authorized documents. 


\section{Contents}

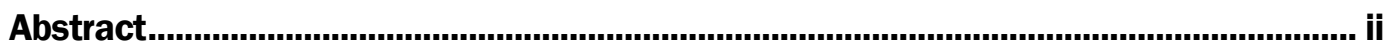

Figures and Tables...................................................................................................................iv

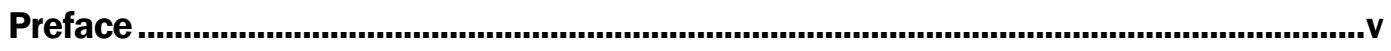

1 Introduction ......................................................................................................... 1

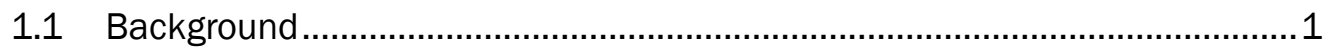

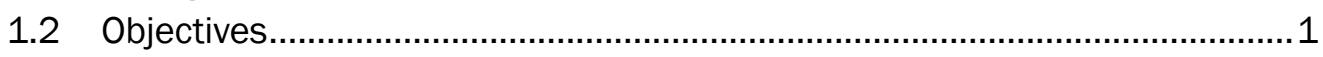

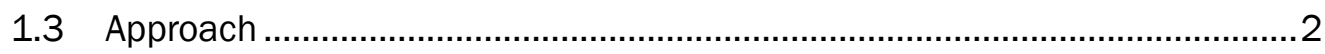

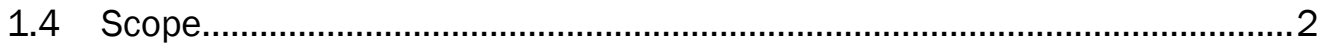

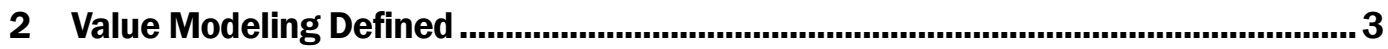

3 US Army Corps of Engineers-Civil Works (USACE-CW) Initial Value Model

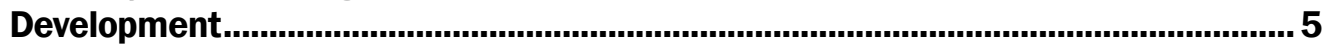

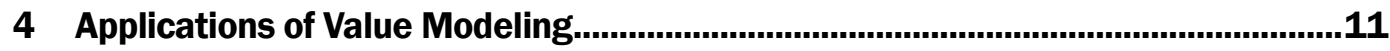

4.1 Portfolio decision analytics .............................................................. 12

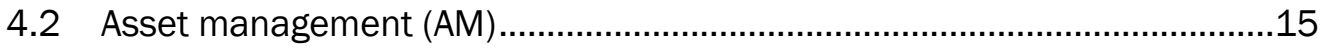

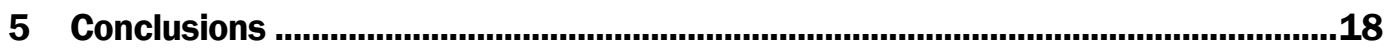

References.............................................................................................................19

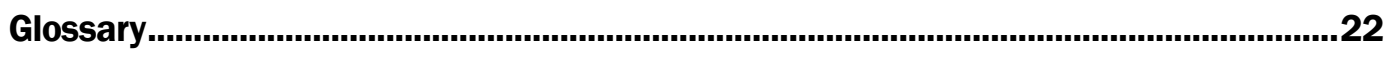

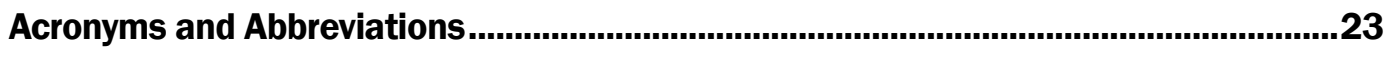

Report Documentation Page 


\section{Figures and Tables}

\section{Figures}

Figure 1. Four types of value functions for increasing value. (after Parnell et al.

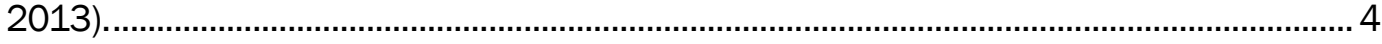

Figure 2. USACE-CW conceptual strategic investment framework. (after Leitch

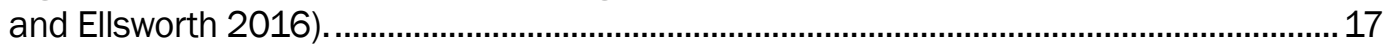

\section{Tables}

Table 1. Original set of means objectives and fundamental objectives.

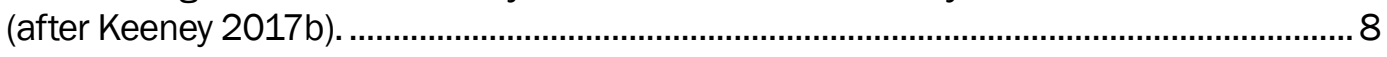

Table 2. Updated 14 fundamental objectives with six sections........................................... 9 


\section{Preface}

This study was conducted for Asset Management, Headquarters, US Army Corps of Engineers (HQ USACE), and the USACE Monitoring Completed Navigation Project (MCNP) Program under Funding Account Code FG46LB; AMSCO Code 008321. Dr. Lyndell Z. Hales was the MCNP Program Manager, and Mr. Peter Dodgion was the Program Manager for Asset Management, HQUSACE.

The work was performed by the Institute for Systems Engineering Research (ISER) Branch, Computational Science and Engineering Division, Information Technology Laboratory (ITL), US Army Engineer Research and Development Center (ERDC) and the Hydrologic Systems Branch, Flood and Storm Protection Division, ERDC Coastal and Hydraulics Laboratory (CHL). At the time of publication of this report, Dr. Simon Goerger was ITL ISER Branch Chief; Dr. Jerry Ballard was ITL Computational Science and Engineering Division Chief; and Dr. Robert Wallace was the ERDC-ITL Technical Director for Engineered Resilient Systems. The Deputy Director of ERDC-ITL was Ms. Patti Duett, and the Director of ERDC-ITL was Dr. David Horner. Dr. Hwai-Ping Cheng was CHL Hydrologic Systems Branch Chief; Dr. Cary A. Talbot was CHL Flood and Storm Protection Division Chief; and Mr. Charles E. Wiggins was the ERDC-CHL Technical Director for Navigation. The Deputy Director of ERDC-CHL was Mr. Jeffrey R. Eckstein, and the Director of ERDC-CHL was Dr. Ty V. Wamsley.

COL Teresa A. Schlosser was the Commander of ERDC, and the Director of ERDC was Dr. David W. Pittman. 


\section{Introduction}

\subsection{Background}

The United States Army Corps of Engineers (USACE) is composed of two major programs: Civil Works and Military Missions (USACE 2017). The Civil Works (CW) program is responsible for approximately $\$ 5$ billion annually and is required to maintain numerous assets nationwide such as locks, dams, levees, and recreation areas. These responsibilities make the task of creating an annual defensible budget difficult. For USACE Civil Works (USACE-CW) specifically, the complexity of this task is compounded exponentially by the number of assets managed. The CW program oversees 11 Business Lines including Navigation, Flood Risk Management, Hydropower, and Recreation (USACE 2017). Each business line is responsible for assets that require annual maintenance, repair, and periodic replacement. Additionally, new assets are added to the CW portfolio as needed. Determining the maintenance, repair, and replacement (MR\&R), along with acquisition activities that will provide the greatest value to the USACE and to the Nation, are annual tasks requiring significant effort. The USACE-CW Asset Management (AM) seeks to create a value model capable of calculating the benefit of MR\&R project alternatives regardless of business line. Furthermore, USACE-CW seeks to explore whether such a value model could be used for the generation of defensible budgets that consistently bring high value to the USACE and to the Nation.

\subsection{Objectives}

This study addresses questions regarding value modeling and how it relates to USACE-CW. While aspects such as metric weights and stakeholder buy-in are critical components of a successful value model, these were not examined within this study. The objectives are to specifically address the following two questions as they relate to USACECW and value modeling:

- What previous work within USACE-CW has been done using a value modeling approach?

- Are there relatable efforts outside of the US federal government that have used value modeling for AM? 


\subsection{Approach}

This study consists of a literature review of value modeling efforts. First, the researchers define value modeling and the different components required to ensure that a value model is successful. Next, previous value model development by Dr. Ralph Keeney (2017a,b) specifically for USACE-CW is examined and summarized. This includes his work identifying strategic objectives, fundamental objectives, and value measure/metrics. Last, applications of value models are examined.

The goal of this literature review is to explore previous attempts at creating a value model to be used for budgeting for USACE-CW and to determine a starting point for future value model creation efforts.

\subsection{Scope}

The purpose of this coastal and hydraulics engineering special report is to explore the applications of value modeling within the USACE-CW program, and in other application areas throughout industry and academia. This report provides an introduction to value models, outlines value modelling efforts previously performed for USACE-CW by Keeney ${ }^{1}$ and Keeney (2017a,b), and reviews recent advances in value modeling including applications in portfolio decision analysis and AM. Finally, this report outlines a suggested path forward to improve upon and gain acceptance for a USACE-CW value model in fiscal year 2020.

${ }^{1}$ Keeney, R. L. Unpublished. Development of a USACE Value Model. 


\section{Value Modeling Defined}

Researchers have used value modeling techniques for years to aid decision-makers with making informed decisions in complex scenarios. Organizations use value modeling techniques to analyze and generate potential solutions because the techniques provide a transparent and consistent methodology for comparisons. According to Trainor and Parnell (2011), value modeling is a method for the determination of "how well candidate solutions attain stakeholder value" (Trainor and Parnell 2011). Value models exist as either qualitative or quantitative models. The qualitative value model "reflects stakeholder values regarding the system's decision problem." The quantitative value models represent a set of "functions, weights, and mathematical equations that are used to evaluate candidate solutions" (Trainor and Parnell 2011). To quantify the attainment of stakeholder value, solution developers must first understand the system traits and factors of greatest importance to their stakeholders. Also known as fundamental objectives, these traits and factors are "the most basic high-level objectives the stakeholders are trying to achieve" (Trainor and Parnell 2011). Once identified, stakeholders and developers alike must decide on a group of value measures, or metrics, that quantify each of these fundamental objectives. After the stakeholders and developers concur on the value measures, they use them to form an agreement on the general form of the value model. Quantitative value models typically take one of three mathematical forms: (1) additive, (2) multiplicative, or (3) multilinear (Keeney 2017a). Additional information regarding these mathematical forms may be found in Keeney (2017a).

Once a mathematical form is selected, stakeholders and developers must construct utility functions that express stakeholder preferences for each value measure. Utility function construction begins by selecting an acceptable range for each value measure. For instance, consider a value measure that may take any whole number between 0 and 100 .

Stakeholders must then choose those points within the allowable range that provide the greatest value and the least value. A rating of zero, for example, may result in no added value to stakeholders while a rating of 100 may bring the greatest possible value to stakeholders. Stakeholders must also understand how their perceived value changes throughout the acceptable range. Perceived value can follow a number of mathematical forms, and it is the responsibility of the value model developer to extract such information from the stakeholder. Value functions can have "four 
basic shapes: (1) linear, (2) concave, (3) convex, and (4) S-curve" (Parnell et al. 2013) as shown in Figure 1.

Figure 1. Four types of value functions for increasing value. (after Parnell et al. 2013).

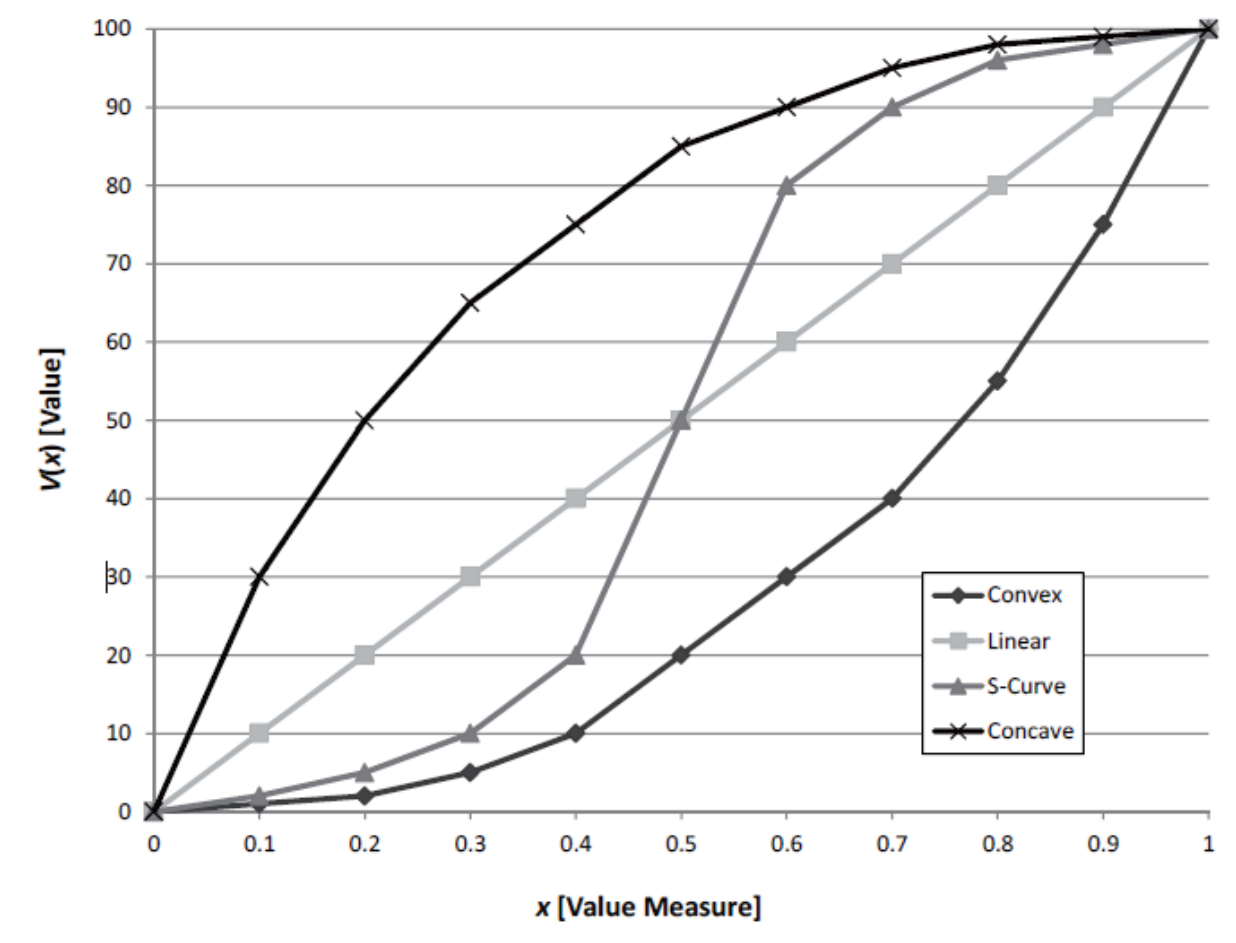

Value model development concludes with the determination of scaling factors. Scaling factors "quantify the trade-offs between value measures" (Parnell and Trainor 2009). Scaling factors indicate the importance of each value measure relative to all other value measures. Multiple techniques exist for the determination of scaling factors such as the swing weight matrix. Advocated by Parnell and Trainor (2009), Trainor and Parnell (2011), and others, the swing weight matrix is a technique for understanding the importance of each value measure and how the value's range impacts the decision. The swing weight matrix is an accepted technique in the value modeling community and could be used in the USACE-CW AM value modeling effort. Once the scaling factors are selected, the value model is complete and can be used to support the decision-making process. 


\section{US Army Corps of Engineers-Civil Works (USACE-CW) Initial Value Model Development}

For many years, USACE-CW has worked to develop balanced budgets that bring high value to USACE and the Nation. As funding levels have decreased however, organizations like the USACE have received increased scrutiny over the work packages and projects chosen for funding. Congress seeks to understand what projects are being funded and why. As a result, USACE has directed time and funding toward the creation of a model or methodology capable of quantifying the value (benefit) of proposed work packages. USACE-CW AM collaborated with Dr. Ralph L. Keeney, a subject matter expert in the field of value modeling, to develop such a model. Keeney delivered three reports, each of which covers various topics within the field of value modeling ${ }^{1}$ (Keeney 2017a,b).

Keeney (2017a) offers an extensive review of value modeling in his report U.S. Army Corps of Engineers Civil Works: Primer on Constructing Value Models and Utility Functions, Asset Management Program. This review discusses the relationship between consequences and value models and the relationship between objective functions and value models. Keeney (2017a) also provides an in-depth overview of the steps required to construct a value model including techniques for discovering relevant values, transforming values to objectives, and identifying fundamental, mean, and end objectives. Keeney (2017a) provides details and practical tips for each step.

Keeney (2017a) begins his review by defining value modeling and by offering a distinction between value models, consequence models, and objective functions. A consequence model "describes how well each of the alternatives achieves each of the objectives" (Keeney 2017a). Simply put, a consequence model outputs the likelihood, or probability, of achieving a set of consequences given an alternative. This information feeds a value model, which calculates the benefit of each given alternative as determined by the consequence model. Value models use "decision maker's preferences" to "indicate which alternatives are better than others" (Keeney 2017a). Together, consequences and value models are

1 Keeney, R. L. Unpublished. Development of a USACE Value Model. 
used to estimate the benefit of a given alternative based on the preferences of a decision-maker.

Keeney (2017a) continues by briefly discussing the differences between objective functions and value models. The three primary differences are listed below:

1. Objective functions are created without decision-maker involvement. Value models, however, are created with decision-maker involvement to model their preferences.

2. Objective functions may be developed in an improvised manner without addressing assumptions. Value models may be derived from theoretical foundations such as the expected utility theory.

3. Objective functions are occasionally created quickly and may use consequence models that are constructed without decision-maker preferences in mind.

The core of Keeney's (2017a,b) papers focuses on seven steps, outlined below, that are necessary to construct a value model. These steps are broken into tasks and subtasks as follows:

1. Identify the fundamental objectives of the decision. To do so, one must first generate a list of relevant values. Relevant values are properties or aspects of a system or situation that are of importance to the decisionmaker.

2. Transform relevant values into objectives. An objective, in this case, is a "specific and consistent format for stating values" in which a "verb is followed by an object" (Keeney 2017a). The phrase "minimize cost" is an example of an objective.

3. Identify means-ends relationships for the fundamental objectives. A fundamental objective identifies "what the decision-maker wishes to achieve by pursuing a decision" (Keeney 2017b). Means objectives, however, "are important only for the influence that better achieving them has on achieving the fundamental objectives" (Keeney 2017b). Identification of the means-ends relationships allows for the selection of the fundamental objectives.

4. Select metrics that measure the achievement of each fundamental objective. This task represents significant effort requiring feedback and buy-in from stakeholders. Keeney (2017a) aggregates metrics into three 
common forms: (1) natural, (2) proxy, and (3) constructed. Note that metrics are not selected for the means objectives.

5. Construct a value model. The value model construction begins with the selection of the appropriate value model form. Three common forms include (1) additive, (2) multiplicative, and (3) multilinear (Keeney 2017a).

6. Evaluate the component utility functions (Keeney 2017a) which includes the creation of value curves and associated mathematical representations for each of the value model metrics.

7. Calculate the weights or scaling factors within the value model. The swing weight matrix is an example method used to determine scaling factors (Parnell and Trainor 2009, Trainor and Parnell 2011).

Overall, Keeney's (2017a) work U.S. Army Corps of Engineers Civil Works: Primer on Constructing Value Models and Utility Functions, Asset Management Program is an extensive review of value modeling tailored for the USACE. In this work, Keeney (2017a) reviews the basics of value modeling, steps through the procedure for creating a value model, and addresses common misconceptions. He also provides examples and insights to help ensure successful value model creation. Keeney (2017a) concludes by including details in regards to an initial USACE-CW value model.

In his article titled Contribution to U.S. Army Corps of Engineers: Value Model Development, Keeney (2017b) provides a high-level review of value modeling and also outlines an initial list of fundamental and means objectives as collected through USACE-CW stakeholder interviews. The high-level overview of value modeling includes a procedure for successfully developing a value model. Of the seven steps identified in his procedure, Keeney (2017b) successfully completes the first three steps, resulting in a comprehensive list of fundamental and means objectives. To generate this list, Keeney (2017b) conducted one-on-one interviews with 15 USACE senior leaders such as the Director of Civil Works, the Flood Risk Management Business Line Manager, and the USACE Chief Economist. From the interview feedback, Keeney (2017b) converted over 200 initial values to a concise set of objectives (Table 1). Keeney (2017b) sorted each objective into one of two bins: (1) fundamental objectives, or (2) means objectives. Keeney (2017b) identified 7 fundamental and 21 means objectives. Means objectives are listed in the left column of Table 1 while the right side of Table 1 includes the list of seven fundamental objectives (shown in gray lines) with the subobjectives (or component 
objectives) listed below each associated fundamental objective (Keeney 2017b). Identifying the fundamental and means objectives is a major step towards the successful creation of a value model for USACE-CW.

Table 1. Original set of means objectives and fundamental objectives (after Keeney 2017b).

\begin{tabular}{|c|c|c|}
\hline MEANS OBJECTIVES & \multicolumn{2}{|l|}{ FUNDAMENTAL OBJECTIVES } \\
\hline Provide quality leadership & \multicolumn{2}{|l|}{ Protect people } \\
\hline Pursue strategic vision and mission & \multirow{2}{*}{$\begin{array}{l}\text { Save lives } \\
\text { Avoid injuries }\end{array}$} & \multirow[t]{2}{*}{ Enhance health } \\
\hline Be a great organization & & \\
\hline Sustain staff knowledge and commitment & \multicolumn{2}{|l|}{ Facilitate commerce } \\
\hline Make quality decisions & \multirow{2}{*}{\multicolumn{2}{|c|}{$\begin{array}{l}\text { Transport cargo } \\
\text { Keep non-water transport costs lower }\end{array}$}} \\
\hline Deliver projects on schedule & & \\
\hline Maintain facilities & \multicolumn{2}{|l|}{ Protect the environment } \\
\hline Do routine maintenance & \multirow{2}{*}{$\begin{array}{l}\text { Restore Eco systems } \\
\text { Preserve habitats } \\
\text { Enhance habitat }\end{array}$} & \multirow{2}{*}{$\begin{array}{l}\text { Reduce invasive species } \\
\text { Promote biodiversity } \\
\text { Sequester carbon }\end{array}$} \\
\hline Make appropriate replacements & & \\
\hline Operate facilities efficiently and effectively & \multicolumn{2}{|l|}{ Enhance quality of life of the public } \\
\hline Operate facilities safely & \multirow{4}{*}{$\begin{array}{l}\text { Provide clean drinking water } \\
\text { Provide electricity } \\
\text { Provide public economic benefits } \\
\text { Help create jobs }\end{array}$} & \multirow{4}{*}{$\begin{array}{l}\text { Provide recreation } \\
\text { Minimize property damage } \\
\text { Enhance development of industry } \\
\text { Provide benefits to businesses }\end{array}$} \\
\hline Store water & & \\
\hline Provide flood management & & \\
\hline Provide fire protection & & \\
\hline Provide cooling water for power plants & \multicolumn{2}{|l|}{ Contribute to national security } \\
\hline Minimize flooding & Support the military mission & Support the Coast Guard \\
\hline Keep navigable waterways clear & \multicolumn{2}{|l|}{ Support other federal agencies } \\
\hline Enhance navigation & \multicolumn{2}{|c|}{ Minimize economic costs to the nation } \\
\hline Move material and products efficiently & \multirow{3}{*}{\multicolumn{2}{|c|}{$\begin{array}{l}\text { Minimize project costs } \\
\text { Minimize operating costs } \\
\text { Provide national economic benefits }\end{array}$}} \\
\hline Transport hazardous cargo safely & & \\
\hline Minimize accidents & & \\
\hline
\end{tabular}

Keeney ${ }^{1}$ presents a completed preliminary value model to USACE Civil Works in his third report, Development of a USACE Value Model. Keeney begins his final deliverable with a finalized list of fundamental objectives followed by a listing and description of each fundamental objectives' potential metric/value measure. The finalized fundamental objectives and value measures are shown in Table 2. Note the differences between the fundamental objectives listed in Table 1 and Table 2.

Keeney ${ }^{1}$ re-aligned the original seven fundamental objectives previously identified to become strategic objectives. A strategic objective is "an organization's articulated aims or responses to address major change or improvement, competitiveness or social issues, and business advantages" (National Institute of Standards and Technology 2016). After meeting with stakeholders at USACE Headquarters, Keeney modified the fundamental objectives to avoid redundancy and to ensure independence among the fundamental objectives. Stakeholders at USACE-CW were satisfied with

1 Keeney, R. L. Unpublished. Development of a USACE Value Model. 
the seven strategic objectives. However, the stakeholders did not agree with the 14 fundamental objectives or their associated proposed value measures/metrics. As a result, future work will focus on refining these value measures/metrics and developing new metrics as needed.

Table 2. Updated 14 fundamental objectives with six sections ${ }^{1}$.

\begin{tabular}{|c|c|c|}
\hline $\begin{array}{l}\text { Strategic } \\
\text { Objectives }\end{array}$ & $\begin{array}{l}\text { Fundamental } \\
\text { Objectives }\end{array}$ & Value Measure/Metric \\
\hline \multirow{2}{*}{$\begin{array}{l}\text { Protect } \\
\text { People }\end{array}$} & Save Lives & Number of statistical lives saved \\
\hline & Avoid Injuries & $\begin{array}{l}\text { Number of statistical serious injuries } \\
\text { avoided }\end{array}$ \\
\hline \multirow{2}{*}{$\begin{array}{l}\text { Facilitate } \\
\text { Commerce }\end{array}$} & $\begin{array}{l}\text { Provide for Water } \\
\text { Transport of Cargo }\end{array}$ & Millions of ton-miles \\
\hline & $\begin{array}{l}\text { Keep non-Water } \\
\text { Transport Costs Lower }\end{array}$ & $\begin{array}{l}\text { Millions of dollars saved due to } \\
\text { competition of water transport }\end{array}$ \\
\hline \multirow{2}{*}{$\begin{array}{l}\text { Protect the } \\
\text { Environment }\end{array}$} & $\begin{array}{l}\text { Protect Local } \\
\text { Environment }\end{array}$ & $\begin{array}{l}\text { Acres of diverse aquatic habitat } \\
\text { reconnected }\end{array}$ \\
\hline & $\begin{array}{l}\text { Reduce Carbon } \\
\text { Emission }\end{array}$ & $\begin{array}{l}\text { Millions of metric-tonnes equivalents } \\
\text { of } \mathrm{CO}_{2} \text { emissions prevented }\end{array}$ \\
\hline \multirow{5}{*}{$\begin{array}{l}\text { Enhance Quality } \\
\text { of Life of the } \\
\text { Public }\end{array}$} & Supply Water Storage & $\begin{array}{l}\text { Annual amount of water storage } \\
\text { contracts in millions of dollars }\end{array}$ \\
\hline & Provide Electricity & Millions of kilowatt hours \\
\hline & $\begin{array}{l}\text { Help Create and Sustain } \\
\text { Jobs }\end{array}$ & $\begin{array}{l}\text { Full-time job equivalents for } \\
\text { businesses outside of USACE }\end{array}$ \\
\hline & Provide Recreation & Recreation-days \\
\hline & $\begin{array}{l}\text { Minimize Private and } \\
\text { Public Property Damage }\end{array}$ & $\begin{array}{l}\text { Dollar value of property protected in } \\
\text { billions of dollars }\end{array}$ \\
\hline \multirow{2}{*}{$\begin{array}{l}\text { Contribute to } \\
\text { National } \\
\text { Security }\end{array}$} & $\begin{array}{l}\text { Support the Military } \\
\text { Mission }\end{array}$ & $\begin{array}{l}\text { Maximum consecutive days of a } \\
\text { strategic port closure }\end{array}$ \\
\hline & Support the Coast Guard & $\begin{array}{l}\text { Maximum consecutive days of a } \\
\text { coastal Coast Guard port closure }\end{array}$ \\
\hline $\begin{array}{l}\text { Minimize } \\
\text { Economic Costs }\end{array}$ & $\begin{array}{l}\text { Minimize Economic } \\
\text { Costs }\end{array}$ & Millions of dollars \\
\hline
\end{tabular}

${ }^{1}$ After Keeney, R. L. Unpublished. Development of a USACE Value Model. 
Keeney's ${ }^{1}$ report also includes utility function construction and a summary review of his approach to calculate the scaling factors. Keeney and his team reviewed stakeholder input to construct the utility functions in the USACE-CW value model, and consulted USACE AM professionals for clarifications. Scaling factors were determined through the systematic discovery of stakeholder preferences using a technique similar to the swing weight matrix. Keeney concludes by reiterating the purpose and benefits of using a value model for USACE-CW AM decision-making. "This value model provides a basis for leaders in different divisions and/or different functions of the Corps to better understand the objectives of others as well as how the objectives of each fits into overall Corps values." 


\section{Applications of Value Modeling}

Researchers performed a literature review to understand the current state of value modeling within the areas of AM, portfolio decision analysis, and budget allocation. The use of value modeling in these fields is well established. Dr. Greg Parnell, a leader in value modeling, published Improving Resource Allocation within the National Reconnaissance Office (Parnell et al. 2002). In this paper, Parnell et al. (2002) described the process used to develop a value model for the National Reconnaissance Office to determine tasks to receive funding based on the value added to the organization. The researchers used a three-step process consisting of decision-maker interviews, value model development, and optimization. The process outlined in Parnell's et al. (2002) work is very similar to the process proposed for the current research with USACE-CW, and closely matches the work of Keeney ${ }^{1}$ (2017a, b). Parnell et al. (2002) demonstrate the usefulness of value modeling in specifying budget allocations, and offers a list of factors that contributed to their project success as listed below:

1. Spend time understanding the decision environment and the stakeholder's strategic goals and challenges.

2. Encourage stakeholders to commit to using the value modeling methodology when making decisions.

3. Clearly and continually explain the methodology to stakeholders so that it is not perceived as a black box (Parnell et al. 2002).

Parnell has performed similar analyses for various military organizations including the United States Army and Air Force. In the book Portfolio Decision Analysis: Improved Methods for Resource Allocation, Burk and Parnell (2011) cite several uses of value modeling to assist with military decisions. Examples include military equipment procurement (Austin and Mitchell 2008) and resource allocation (Buede and Bresnick 2007). Burk and Parnell (2011) also highlight the many different tools used to make military decisions. Popular methods include optimization, the analytical hierarchy process, and Pareto analysis. Of the literature reviewed however, most examples consist of utilizing value modeling to aid in decisionmaking processes.

1 Keeney, R. L. Unpublished. Development of a USACE Value Model. 
Curran et al. (2014) offer another example of using value models and other techniques to determine ideal locations for humanitarian assistance based on the following four factors: (1) multi-hazard exposure, (2) resilience factors, (2) investment sustainability, and (4) strategic investment. Researchers Scala and Pazour (2016) utilized value modeling in efforts to improve naval sea-based resupply missions. The US Navy uses specialized vessels to store cargo and supplies at sea. Referred to as sea-based resupply, this form of tactical support presents a unique set of issues to include tracking assets. According to Scala and Pazour (2016), "assets are not automatically tracked" while they are being shifted in their cargo location or being retrieved for delivery. This lack of tracking results in uncertainties about the asset's true location and tracking delays. Scala and Pazour (2016) developed a value model to assess the benefit of various asset tracking technologies for naval sea-based resupply missions. These articles by Curren et al. (2014) and Scala and Pazour (2016) represent a body of work that demonstrates the acceptance of value modeling as a valuable decision-making tool within the Department of Defense (DoD) and other industries.

\subsection{Portfolio decision analytics}

Decision-makers and analysts have used value modeling to support portfolio-level decision-making as well. Commonly referred to as portfolio decision analysis, this subset of decision analytics commonly employs a variety of tools and methodologies to include value modeling. The phrase portfolio decision analysis can be formally defined as "a body of theory, methods, and practice which seeks to help decision-makers make informed multiple selections from a discrete set of alternatives through mathematical modeling that accounts for relevant constraints, preferences, and uncertainties" (Burk and Parnell 2011). The tools and methods comprising portfolio decision analytics have been used in various fields.

Kurth et al. (2017) used value modeling and optimization to improve the U.S. Department of Energy's carbon capture and storage research and development budget. The researchers assessed portfolio value using three metrics: (1) Pathway Aggregated Technology Readiness Level, (2) Applicability to Fleet, and (3) Cost Impact. Kurth et al. (2017) then used optimization to determine the level of funding to provide to each of three carbon capture and storage technologies to maximize the overall portfolio value. Lahtinen et al. (2017) provided a primer on portfolio decision analytics for members of the environmental decision-making community 
in their paper Portfolio Decision Analysis Methods in Environmental Decision-making. In their work, Lahtinen et al. (2017) offered an in-depth discussion of portfolio decision analysis by reviewing approximately five decision analysis methodologies. Their research provided a brief literature review of the uses of portfolio decision analysis within environmental decision-making. The team concluded by introducing a framework for portfolio decision analysis within environmental decision-making while also providing a realistic example of its use by examining a hypothetical water supply problem (Lahtinen et al. 2017).

In their paper Disagreement Constrained Action Selection in Participatory Portfolio Decision Analysis, Fasth et al. (2016) quantify stakeholder disagreement and use this factor to constrain their portfolio decision analysis. The researchers use basic value modeling principles to facilitate analysis and claim that their publication is the first use of stakeholder disagreement as a decision analysis constraint. Overall, Fasth et al. (2016) use the example of urban development to demonstrate the utility of considering stakeholder disagreement in a decision-making scenario.

Davis et al. (2016) discuss using the Capability Portfolio Analysis Tool (CPAT) to leverage various methodologies for the optimization of the Army's Combat Ground Vehicle program investment portfolio decisions in their paper Maximizing the U.S. Army's Future Contribution to Global Security Using the Capability Portfolio Analysis Tool (CPAT). Using Mixed-Integer Linear Programming, the CPAT incorporates business rules and varying stakeholder requirements to provide U.S. Army senior leaders with multiple courses of action along with associated portfolio impacts. In developing the CPAT tool, researchers addressed multiple levels of stakeholder requirements through continual stakeholder elicitation, developed value models, assigned swing matrix weightings, and created value functions. Collectively, the value models included 49 individual measures encompassing six major categories. The researchers suggest that this methodology and tool could potentially be leveraged to support other U.S. Army portfolio analysis efforts (Davis et al. 2016).

Sun et al. (2017) investigate a methodology which evaluates both the "internal and external performance" combined with the "direct and indirect value" of bridges to support infrastructure decision-making. The researchers' methodology considers a bridge's risk and value at both an individual project level and a network-connected level. Furthermore, the 
bridge replacement value is calculated as a function of direct construction cost and implicit bridge value, with respect to the traffic environment (Sun et al. 2017). The proposed decision methodology is applied in an evaluation of bridges in Korea and provides a suggested investment priority to align with the organization's AM objectives (Sun et al. 2017).

Researchers have developed numerous methods and techniques to facilitate portfolio decision-making. However, some methods lose sight of the organization's strategic goals. Arif and Bayraktar (2018) performed a literature review to understand the current state of US infrastructure decision-making practices by focusing on U.S. Department of Transportation (DOT) district level decision-making. The authors developed a survey using findings from a literature search and administered the survey to district-level DOT. Over $90 \%$ of those surveyed indicated that they account for the physical state of the infrastructure when making major decisions. Additionally, districts consider structure usage as a primary factor in decision-making. The decision-making process includes leveraging economic analysis data as well as state and local government consultations. The article includes an overview of performance-measurement factors, to include strategic importance, socioeconomic contribution, and infrastructure utilization as well as various infrastructure ratings (e.g., bridge health index, structural deficiency). Most importantly, the survey reveals a lack of clear alignment to strategic importance at the DOT district level (Arif and Bayraktar 2018).

Prior research in the field of portfolio decision analysis contains analyses of methods and techniques for the optimal selection of decisions. In some cases, value models are not an integral part of a portfolio decision analysis. While some techniques disregard organizational strategic goals entirely, France-Mensah and O'Brien (2018) successfully consider organizational goals without the use of value modeling. Their research provides a highlevel overview of transportation infrastructure maintenance and repair decision analysis in the article Budget Allocation Models for Pavement Maintenance and Rehabilitation: Comparative Case Study. The authors reveal that, in the establishment of funding, transportation engineers consider the owning organization's strategic goals, regional network objectives, condition of the highway, and political complications. The researchers also mention the utilization of pavement management systems to assist with making decisions. Overall, the article compares three different techniques to aid in the maintenance and repair decision-making 
process, including a cost-benefit analysis approach, integer-linear programming (ILP), and a combination of the two methods described as the "decision tree + needs-based" method. Based on the measures such as highest average network road condition score and achieving strategic goals for pavement condition, the ILP method performed significantly better than the other two methods (France-Mensah and O'Brien 2018).

Overall, the literature reveals that applications of portfolio decision analysis are wide-ranging. Researchers around the world utilize numerous techniques to make well-informed decisions; however, many lose sight of organizational strategic goals. Value modeling, when used to assist with complex portfolio decision problems, can support leadership with complex and difficult decisions.

\subsection{Asset management (AM)}

Literature reveals that AM research has leveraged value modeling to optimize repair, replacement, and acquisition activities. An asset, as defined by ISO (2014), is "an item, thing or entity that has potential or actual value to an organization." AM "involves the balancing of costs, opportunities, and risks against the desired performance of assets, to achieve the organizational objectives" (ISO 2014). Researchers and organizations continue to explore the management of infrastructure assets in the United States. The United States has the largest network of roadways in the world and has approximately 25 years of experience in dealing with AM systems (Beitelmal et al. 2017). Despite this extensive experience, organizations in the United States still have difficulty managing infrastructure assets (Beitelmal et al. 2017). Research has identified many barriers to implementing an AM system with barrier categories including planning/decision-making, managerial/organizational, information resources, human resources, social, finance resources, and local knowledge. Previous research has investigated several methods and techniques to assist with the effective management of assets.

School systems offer multiple examples of AM challenges. According to the American Society of Civil Engineers, the United States of America's school infrastructure received a D+ grade on its 2017 infrastructure report card (ASCE 2017). The United States "underinvests in school facilities, leaving an estimated $\$ 38$ billion annual gap" in funding needed to maintain facilities (ASCE 2017). The report cites the market crash of 2008 as a 
significant contributor to this poor score. Most school systems reduced funding in 2008 and have yet to restore funding to previous historic levels. Researchers Rashedi and Hegazy (2016) tackle the school system AM problem by creating a system dynamics approach for the analysis of school system budgeting policies. With this model, researchers performed budget optimization studies and tested varying budget strategies for the repair and construction of school infrastructure in Toronto, Canada.

Elcheikh and Burrow (2107) explore a methodology that considers risk and data uncertainty in the AM decision-making process as applied to aging canal systems. The proposed framework investigates and determines the dominant assets in a system. The researchers define a dominant asset as an asset having the most significant contribution to cost increases, and use a Monte-Carlo simulation for uncertainty analysis of the dominant asset conditions. This information updates the ranges of estimated maintenance costs. The updated costs inform budget availability and prioritization. The researchers applied the proposed framework to the Canal and River Trust canals and rivers in England and Wales to help inform the AM decision-making process. While the framework aids in decision-making, the authors suggest consideration of organizational factors to support successful implementation such as obtaining leadership support, possessing the capability to assess and access reliable asset data, and communicating with stakeholders throughout the process (Elcheikh and Burrow 2017).

Leitch and Ellsworth (2016) provide an overview of the vast USACE-CW asset portfolio and future management strategies in their report Implementing Asset Management for the U.S. Army Corps of Engineers Civil Works. The USACE-CW portfolio includes $\$ 250$ billion worth of capital assets. As infrastructure ages and budgets decrease, new AM strategies are required. Leitch and Ellsworth (2016) outline the future USACE-CW AM strategy for multi-asset, multi-purpose, strategic investments as depicted in Figure 2. The USACE-CW AM conceptual strategic investment framework includes three pillars: (1) Assets, (2) Mission, and (3) Value to the Nation. USACE-CW must bring value to the nation and reduce risk by successfully managing the condition of its assets such that the USACE mission is not degraded. 
Figure 2. USACE-CW conceptual strategic investment framework. (after Leitch and Ellsworth 2016).

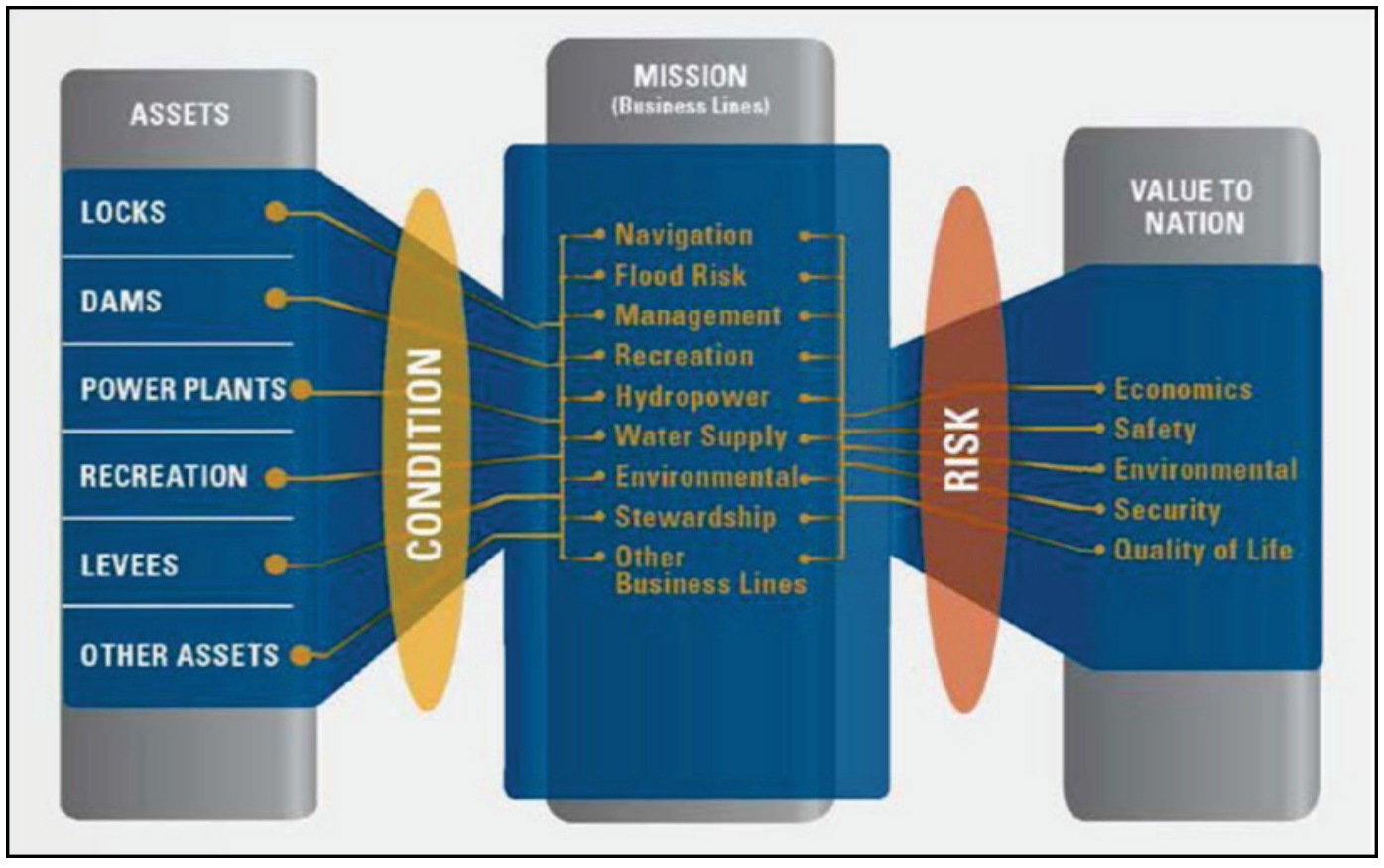

The CW missions include flood risk management, navigation (including harbors and waterways), hydropower, recreation, environmental stewardship and restoration, water supply, and emergency response.

The USACE AM objective is described in three focus areas. Focus Area 1 relates to developing the framework for the risk-informed AM strategy. Focus Area 2 is concerned with evaluating the interactions and dependencies of systems and assets within the asset portfolio across the entire life cycle. This focus area also relates to understanding how USACE assets affect the Value to the Nation. Focus Area 3 includes a variety of activities such as integrating activities across the organization, establishing and informing others of new business processes and principles, determining performance metrics, and testing and validating the new processes to support long-term credibility and sustainment. The USACE AM process aligns to ISO (2014) processes (Leitch and Ellsworth 2016).

From the literature, value modeling appears to have a more limited application in the area of AM. Many researchers and organizations have investigated other AM techniques and found implementation success. Regardless, value modeling could prove useful to decision-makers in this field because it weighs system performance, cost, and risk against organizational strategies and goals. 


\section{Conclusions}

This research seeks to support the USACE-CW AM goal of generating defensible future budgets by developing a tool capable of calculating project value regardless of business line. Creating such a tool that could integrate with the AM decision-making process could support the USACECW effort of generating defensible budgets that could consistently bring high value to the USACE and to the Nation. Researchers and practitioners have successfully leveraged value modeling to support complex decisions. Value modeling is a widely used and accepted decision-making tool across multiple use cases. Value modeling differs from other decision-making techniques as it uses stakeholder and organizational goals and preferences to form the basis of the methodology. Previous research illustrates the use of value models to aid with decision-making processes in areas related to transportation infrastructure, environmental projects, asset-tracking systems, and DoD applications. When considering the complexity of USACE assets and the number of stakeholder priorities to consider, value modeling could support the CW AM decision-making process. Initial USACE-CW efforts included collaborating with a value model subject matter expert, Dr. Ralph Keeney, who supported efforts to develop an initial USACE-CW value model. The initial value model effort established a starting point for future metric research, which requires additional refinement and improvements.

Future research should build upon the USACE-CW fundamental objectives established and should revisit the associated value measures/metrics. USACE-CW stakeholders expressed the need to investigate alternative methods of quantifying aspects of the initial value model. Future research should include performing a literature review of environmental metrics followed by a review of all metrics. Future research should also recommend a new list of metrics to communicate to and coordinate with stakeholders for approval. Once all metrics are established and accepted, USACE should construct utility functions, calculate scaling factors, and build a new value model for USACE-CW. 


\section{References}

Arif, F., and M. E. Bayraktar. 2018. "Current Practices of Transportation Infrastructure Maintenance Investment Decision Making in the United States." Journal of Transportation Engineering, Part A: Systems 144(6). https://doi.org/10.1061/JTEPBS.0000137

ASCE (American Society of Civil Engineers). 2017. America's Infrastructure Report Cards - Schools. https://www.infrastructurereportcard.org/wpcontent/uploads/2017/01/Schools-Final.pdf

Austin, J., and I. M. Mitchell. 2008. "Bringing Value Focused Thinking to Bear on Equipment Procurement.” Military Operations Research 13(2): 33-46.

Beitelmal, W., K. R. Molenaar, A. Javernick-Will, and E. Pellicer. 2017. "Challenges and Barriers to Establishing Infrastructure Asset Management: A Comparative Study between Libya and the USA." Engineering, Construction and Architectural Management 24(6): 1184-1202. https://doi.org/10.1108/ECAM-12-2015-0200

Buede, D. M., and T. A. Bresnick. 2007. "Applications of Decision Analysis to the Military Systems Acquisition Process." Advances in Decision Analysis: From Foundations to Applications. Cambridge: Cambridge University Press. https://doi.org/10.1017/CB09780511611308.027

Burk, R. C., and G. S. Parnell. 2011. "Portfolio Decision Analysis: Lessons from Military Applications." Portfolio Decision Analysis: Improved Methods for Resource Allocation. Edited by A. Salo, J. Keisler, and A. Morton. Springer Science+Business Media, LLC.

Curran, R. W., M. E. Bates, and H. M. Bell. 2014. "Multi-Criteria Decision Analysis Approach to Site Suitability of U.S. Department of Defense Humanitarian Assistance Projects." Procedia Engineering 78: 59-63. https://doi.org/10.1016/i.proeng.2014.07.039

Davis, S. J., S. B. Edwards, G. E. Teper, D. G. Bassett, M. J. McCarthy, S. C. Johnson, ...R. E. Rice. 2016. "Maximizing the U.S. Army's Future Contribution to Global Security Using the Capability Portfolio Analysis Tool (CPAT).” Interfaces 46(1): 91-108. https://doi.org/10.1287/inte.2015.0824

Elcheikh, M., and M. P. N. Burrow. 2017. "Uncertainties in Forecasting Maintenance Costs for Asset Management: Application to an Aging Canal System.” ASCEASME Journal of Risk and Uncertainty in Engineering Systems, Part A: Civil Engineering 3(1). https://doi.org/10.1061/AJRUA6.0000890

Fasth, T., A. Larsson, and M. Kalinina. 2016. "Disagreement Constrained Action Selection in Participatory Portfolio Decision Analysis.” International Journal of Innovation, Management and Technology 7(1): 1-7. https://doi.org/10.18178/ijimt.2016.7.1.636 
France-Mensah, J., and W. O’Brien. 2018. "Budget Allocation Models for Pavement Maintenance and Rehabilitation: Comparative Case Study." Journal of Management in Engineering 34(2). https://doi.org/10.1061/(ASCE)ME.1943$\underline{5479.0000599}$

International Organization for Standardization. 2014. Asset Management - Overview, Principles, and Terminology. ISO 55000:2014(E). First edition, 2014-01-15; Corrected version, 2014-03-15. International Standard.

Keeney, R. L. 2017a. U.S. Army Corps of Engineers Civil Works: Primer on Constructing Value Models and Utility Functions: Asset Management Program. Washington, DC: US Army Corps of Engineers.

Keeney, R. L. 2017b. Contribution to U.S. Army Corps of Engineers: Value Model Development. Washington, DC: US Army Corps of Engineers.

Kurth, M., J. M. Keisler, M. E. Bates, T. S. Bridges, J. Summers, and I. Linkov. 2017. “A Portfolio Decision Analysis Approach to Support Energy Research and Development Resource Allocation.” Energy Policy 105(January 2016): 128-135. https://doi.org/10.1016/i.enpol.2017.02.030

Lahtinen, T. J., R. P. Hämäläinen, and J. Liesiö. 2017. "Portfolio Decision Analysis Methods in Environmental Decision Making." Environmental Modelling and Software 94: 73-86. https://doi.org/10.1016/j.envsoft.2017.04.001

Leitch, R. B., and D. E. Ellsworth. 2016. Implementing Asset Management for the U.S. Army Corps of Engineers Civil Works. Institution of Engineering Technology. https://ieeexplore.ieee.org/document/8358926

National Institute of Standards and Technology. 2016. Baldrige Key Terms. https://www.nist.gov/baldrige/self-assessing/baldrige-key-terms

Parnell, G. S., G. E. Bennett, J. A. Engelbrecht, R. Szafranski, and D. W. Wells. 2002. "Improving Resource Allocation within the National Reconnaissance Office." Interfaces 32(3): 77-90. https://doi.org/10.1287/inte.32.3.77.40

Parnell, G. S., T. A. Bresnick, S. N. Tani, and E. R. Johnson. 2013. Handbook of Decision Analysis. Handbook of Decision Analysis. https://doi.org/10.1002/9781118515853

Parnell, G. S., and T. E. Trainor. 2009. "Using the Swing Weight Matrix to Weight Multiple Objectives." INCOSE International Symposium 19(1): 283-298. https://doi.org/10.1002/j.2334-5837.2009.tb00949.x

Rashedi, R., and T. Hegazy. 2016. "Examining Budget Policies for New and Existing Facilities: A System Dynamics Approach.” Canadian Journal of Civil Engineering 43(6): 511-522. https://doi.org/10.1139/cjce-2015-0486

Scala, N. M., and J. A. Pazour. 2016. "A Value Model for Asset Tracking Technology to Support Naval Sea-Based Resupply.” EMJ - Engineering Management Journal 28(2): 120-130. https://doi.org/10.1080/10429247.2016.1168502

Sun, J., K. Park, and M.-J. Lee. 2017. "A Multi-Level Asset Management Decision Method Considering the Risk and Value of Bridges." Journal of Asian Architecture and Building Engineering 16(1): 163-170. https://doi.org/10.3130/jaabe.16.163 
Trainor, T., and G. S. Parnell. 2011. "Problem Definition.” Decision Making in Systems Engineering and Management, 2nd ed. Edited by G. S. Parnell, P. J. Driscoll, and D. L. Henderson, 297-352. Hoboken, NJ: John Wiley and Sons, Inc.

USACE (US Army Corps of Engineers). 2017. Fiscal Year 2017: United States Army Annual Financial Report, U.S. Army Corps of Engineers - Civil Works. Institution of Engineering and Technology.

https://www.publications.usace.army.mil/Portals/76/Publications/Miscellaneous/FY_2017.pdf ?ver=2017-11-17-071434-543 


\section{Glossary}

Consequence Model - a model that describes how well solution alternatives achieve stakeholder objectives (Keeney 2017a)

Fundamental Objectives - traits and factors of a system that represent "the most basic high-level objectives the stakeholders are trying to achieve" (Trainor and Parnell 2011)

Metrics - quantify a fundamental objective; also referred to as a value measure (Trainor and Parnell 2011)

Means Objective - an objective that "influences, positively or negatively, the degree to which a second objective is achieved" (Keeney 2017a)

Objective - a "specific and consistent format for stating values" in which a "verb is followed by an object" (Keeney 2017a)

Portfolio Decision Analysis - "a body of theory, methods, and practice which seeks to help decision makers make informed multiple selections from a discrete set of alternatives through mathematical modeling that accounts for relevant constraints, preferences, and uncertainties" (Burk and Parnell 2011)

Scaling Factor - weighting factors present in value models that "quantify the tradeoffs between value measures" (Parnell and Trainor 2009)

Strategic Objective - "an organization's articulated aims or responses to address major change or improvement, competitiveness or social issues, and business advantages" (National Institute of Standards and Technology 2016)

Swing Weight Matrix - a technique for understanding the importance of each value measure and how this perceived importance changes as the value measure swings through its acceptable range (Parnell and Trainor 2009; Trainor and Parnell 2011)

Utility Function - "a function that assigns a value to a value measure's score; a value function measures returns to scale over the range of the value measure" (Trainor and Parnell 2011)

Value Measure - assessment scale that measures how well an objective is attained; also referred to as metrics (Trainor and Parnell 2011)

Value Modeling - a method for the determination of "how well candidate solutions attain stakeholder value" (Trainor and Parnell 2011) 


\section{Acronyms and Abbreviations}

$\begin{array}{ll}\text { AM } & \text { Asset Management } \\ \text { CPAT } & \text { Capability Portfolio Analysis Tool } \\ \text { CW } & \text { Civil Works } \\ \text { DoD } & \text { Department of Defense } \\ \text { DOT } & \text { Department of Transportation } \\ \text { ILP } & \text { integer-linear programming } \\ \text { MR\&R } & \text { maintenance, repair, and replacement } \\ \text { USACE } & \text { US Army Corps of Engineers } \\ \text { USACE-CW } & \text { US Army Corps of Engineers-Civil Works }\end{array}$




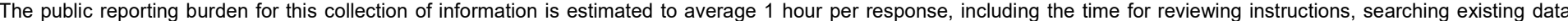

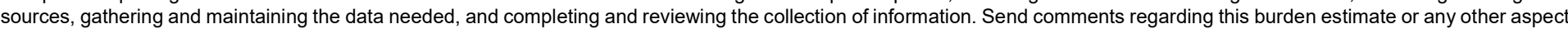

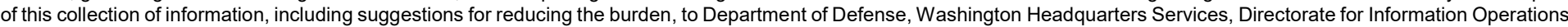

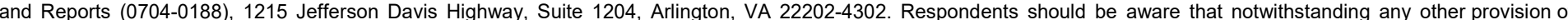
law, no person shall be subject to any penalty for failing to comply with a collection of information if it does not display a currently valid OMB control number.

PLEASE DO NOT RETURN YOUR FORM TO THE ABOVE ADDRESS.

\begin{tabular}{l|l|l}
$\begin{array}{l}\text { 1. REPORT DATE } \\
\text { June } 2020\end{array}$ & $\begin{array}{l}\text { 2. REPORT TYPE } \\
\text { Final Report }\end{array}$ & 3. DATES COVERED (FrOm - To)
\end{tabular}

\section{TITLE AND SUBTITLE}

Applications of Value Modeling to USACE Civil Works and Beyond 5a. CONTRACT NUMBER

5b. GRANT NUMBER

5c. PROGRAM ELEMENT NUMBER

5d. PROJECT NUMBER

5e. TASK NUMBER

5f. WORK UNIT NUMBER

8. PERFORMING ORGANIZATION REPORT

NUMBER

U.S. Army Engineer Research and

Development Center

3909 Halls Ferry Road

ERDC SR-20-1

Development Center

3909 Halls Ferry Road

Vicksburg, MS 39180-6199

\section{SPONSORING/MONITORING AGENCY}

NAME(S) AND ADDRESS(ES)

Asset Management; Headquarters, US Army

Corps of Engineers

Washington, DC 20001

Vicksburg, MS 39180-6199

Monitoring Completed Navigation Projects

Vicksburg, MS 39180

\section{SPONSOR/MONITOR'S ACRONYM(S)}

USACE

\section{SPONSOR/MONITOR'S} REPORT NUMBER(S)

\section{DISTRIBUTION/AVAILABILITY STATEMENT}

Approved for public release; distribution is unlimited.

\section{SUPPLEMENTARY NOTES}

Funding Account Code FG46LB; AMSCO Code 008321

\section{ABSTRACT}

The US Army Corps of Engineers (USACE) Civil Works (CW) portfolio includes $\$ 250$ billion worth of capital assets. As infrastructure ages and budgets change, new asset management (AM) investment strategies are required to support the maintenance, repair, and replacement (MR\&R) of these assets while also providing the greatest value to the USACE and to the Nation. Shrinking budgets and increased scrutiny of government expenditures drive efforts to determine how best to optimize government funds for infrastructure improvement. As a result, USACE-CW AM seeks to create a value model capable of calculating the benefit of MR\&R project alternatives regardless of business line. Furthermore, USACE-CW seeks to explore whether such a value model could be used for the generation of defensible budgets that consistently bring high value to the USACE and to the Nation. Thus, this special report reviews pas USACE CW efforts to develop a value model for decision analytics. This report also provides an introduction to value modeling while covering applications of value modeling in multiple areas, including AM and portfolio decision analytics.

\section{SUBJECT TERMS}

Civil engineering, Decision making, Infrastructure (Economics), Public works-Maintenance and repair, System analysis, Systems engineering, United States. Army. Corps of Engineers-Civil functions

\section{SECURITY CLASSIFICATION OF:}

\section{a. REPORT}

Unclassified

\begin{tabular}{|l|l|}
\hline b. ABSTRACT & c. THIS PAGE \\
Unclassified & Unclassified \\
\hline
\end{tabular}

17. LIMITATION OF ABSTRACT

SAR
18. NUMBER

OF PAGES

31 19a. NAME OF RESPONSIBLE PERSON Kayla A. Cotterman

19b. TELEPHONE NUMBER (Include area code) 601-634- 5507 
